\title{
Music as a Tool for Promoting Environmental Awareness. Experiences of Undergraduate Education Students on the Production of Video Tales in the COVID-19 Pandemic
}

\author{
María del Valle de Moya Martínez (D) and Bohdan Syroyid Syroyid *(D) \\ Department of Physical Education, Arts Education, and Music, Faculty of Education of Albacete, \\ University of Castilla-La Mancha, 13001 Ciudad Real, Spain; mariavallede.moya@uclm.es \\ * Correspondence: bohdan.syroyid@uclm.es
}

check for

updates

Citation: de Moya Martínez, M.d.V.; Syroyid Syroyid, B. Music as a Tool for Promoting Environmental

Awareness. Experiences of

Undergraduate Education Students on the Production of Video Tales in the COVID-19 Pandemic. Educ. Sci. 2021, 11, 582. https://doi.org/

10.3390/educsci11100582

Academic Editor: Gary McPherson

Received: 17 August 2021

Accepted: 22 September 2021

Published: 26 September 2021

Publisher's Note: MDPI stays neutral with regard to jurisdictional claims in published maps and institutional affiliations.

Copyright: (C) 2021 by the authors Licensee MDPI, Basel, Switzerland. This article is an open access article distributed under the terms and conditions of the Creative Commons Attribution (CC BY) license (https:/ / creativecommons.org/licenses/by/ $4.0 /)$.
Abstract: This paper elaborates on the didactic implementation of musical theater with undergraduate education students. Students had to select, prepare, justify, design, elaborate, rehearse, stage, and record an educational tale that targets ecological and environmental values in its main plot or storyline. Due to the COVID-19 pandemic, the implementation of this didactic proposal went online, and the interactions between students took place through video calls. This study surveyed a sample of 86 participants $(n=86)$ from a population of 116 students $(N=116)$ from the Faculty of Education of Albacete (UCLM) to investigate the advantages and disadvantages of carrying out this activity in an online format. The main challenges exposed the complexity of coordinating a team in a completely online format, problems related to physical isolation, and the limited access to a high-quality internet connection. The reported benefits included the development of digital competences, the interactions through social media, and creative thinking. Most students viewed this activity as didactically innovative and $98.84 \%$ agreed that musical tales and musical theater can be useful for promoting environmental awareness.

Keywords: COVID-19 pandemic; environmental awareness; music education; online education; undergraduate students

\section{Introduction}

In the Spanish educational system, teachers of early childhood and primary schools receive formal training through official undergraduate programs [1]. These programs span four academic years and a total of 240 ECTS (European Credit Transfer and Accumulation System) credits and include the writing and defending of a bachelor's thesis (also known as TFG, in Spanish). A series of concentrations or majors are available to students in their junior and senior years, e.g., music, physical education, therapeutic pedagogy, foreign language, natural sciences, information, and communication technologies in education, to cite a few. Basic musical training is a mandatory component of the core curriculum of all undergraduate programs in early childhood and primary school teaching.

The latest educational reforms in Spain argue that teachers should seek meaningful learning in their students. Teaching students to assess a set of key skills (to know, to know-how, and to know how to be) achieves meaningful learning in this context [2]. To make teaching and learning proactive and effective, a teacher should consider these three aspects: (a) experimentation and collaborative learning; (b) adequate teaching methods; and (c) a positive classroom environment. These pedagogical aspects can help to promote personal and social responsibility in students [3]. Presently, in the Spanish curriculum music is taught in primary schools as a subject called Arts Education which can be divided into Plastic and Visual Education, and Music and Dance [4].

The importance and relevance of music education in general public schools is defended by multiple authors [5-9]. There are many publications that attribute many developmental 
benefits to music - cognitive, psychomotor, and socio-emotional [10-17]. However, recent meta-analyses and systematic reviews argue that empirical evidence for the improvement of cognitive and academic skills from music training is rather limited [18-22]. It should be noted that these negative reviews do not diminish the aesthetic value of music and its importance in society, as well as other benefits derived from musical training. Musical experiences can have transformative psychological effects on listeners in the domain of music therapy [23-25]. Additionally, making music can have positive personal and social outcomes for a student, helping them to overcome challenges, develop teamwork and cooperation skills, build self-confidence, develop a sense of self-achievement, and feel more integrated with a sense of belonging to a group [26]. This paper will argue that music can be a powerful vehicle for promoting ecological values and raising students' environmental awareness and care.

\subsection{Environmental Awareness}

Presently, there is an increased awareness of the need to care for, respect, and support our natural environment and ecological behaviors from early childhood. In Spain, the General Organic Law of the System of Education of 1990 (known as LOGSE, in Spanish) [27] introduced the concept of environmental education in the curriculum by focusing on the importance of caring for the environment, promoting more responsible consumption by reducing, reusing, and recycling wastes, warning students about the setbacks of nonrenewable energies, and raising awareness of air pollution, among other issues. The United Nations declared 2005-2014 as the Decade of Education for Sustainable Development [28], promoting new initiatives to be incorporated into education [29].

The number of publications featuring ecological values and environmental awareness has significantly grown in recent decades, particularly in the domain of education [30-39]. Dunlap and Jones defined environmental concern as "the degree to which people are aware of environmental problems regarding the environment and support efforts to solve them and/or indicate the willingness to contribute personally to their solution" [35] (p. 485). Environmental awareness includes a set of favorable values and beliefs about caring for and respecting the environment and reducing the environmental impact of human actions [36,37]. Some issues of environmental concern are the extinction of species, the limitations drawn from non-renewable energies, the management of natural resources, global warming, and air, soil, and water pollution, among other issues [38]. Environmental awareness requires a specialized set of knowledge and experiences, and calls for action to improve the environment in which present and future generations live [39,40].

Curtis et al. [41] have reviewed eight case studies that include ecological proposals through the arts. Their research suggests that there are at least three ways in which the arts can contribute to ecological and environmental awareness: (a) communicating information (through the message of the work of art itself); (b) creating empathy for the natural environment (developing an emotional rapport with nature); and (c) embedding the arts in ecologically sustainable mediums (e.g., creating art with recycled materials). Woynarski [42] reaffirms the relevance that the arts and music have in promoting ecological thinking: "Ecological thinking is to do with art, philosophy, literature, music, and culture as ecology includes all the ways we imagine how we live together" (p. 8).

\subsection{Musical Tales in Music Education}

A tale is a short fictional story with a small number of characters and a simple plot [43]. Tales are a powerful tool for developing transversal competences, as they stimulate creativity and imagination, awaken students' sensitivity, aid in developing their personality and critical judgment, and promote social values $[44,45]$. In education, tales present multiple benefits in all areas of the curriculum through instating interdisciplinary rapport and inclusive, active-learning methodologies. Preparing, rehearsing, and staging tales in the classroom is a project-based learning methodology where a student's final performance becomes a recorded educational product. One of the outcomes of a proper educational 
implementation of tales is constructive learning, which implies integrating and connecting new knowledge and experiences with previous ones [46].

A musical tale unites narrative and dramatic elements with musical expressions (dancing, singing, and playing instruments) [47]. It is necessary to account for the didactic goals that one is pursuing when establishing an action plan for designing and staging a musical tale as a short play. These goals can target diverse ecological themes in an interdisciplinary way. To this end, the plot of a musical tale can be invented, adapted, or retrieved from similar proposals [46]. Musical tales are an excellent didactic resource for value-based education, raising ecological awareness and critical thinking for environmental care $[48,49]$. At the same time, the design, preparation, rehearsal, and staging of musical tales as short educational plays help students to learn new concepts and positively affects their integral development as humans [50].

\subsection{Research Goals}

The objectives of this study were to analyze the students' perceived challenges, benefits, and the perceived relevance of a didactic implementation with musical theater as a teaching and learning methodology for online education. This study aimed to identify (i) the challenges and benefits experienced by students in the online didactic implementation of the musical tale and (ii) the overall didactic benefits reported by the students working on the musical tale project.

\section{Materials and Methods}

The present study is descriptive, mixed with quantitative and qualitative approaches. It examined a didactic implementation that moved online due to the COVID-19 pandemic. In this implementation, students engaged in a team project requiring them to select, prepare, justify, design, elaborate, rehearse, stage, and record an educational tale making use of musical expressions (singing, dancing, and playing instruments). The storylines and plots of these musical tales aimed to raise environmental awareness and to promote ecological thinking. This study followed Supplementary Materials: Checklist for Reporting Results of Internet E-Surveys (CHERRIES) [51].

\subsection{Participants}

The sample consisted of 86 participants $(n=86)$ out of a total of 116 students $(N=116$, female $=88$ ) enrolled in a music education course in their third year of the bachelor's degree of Primary Education Teaching. The music education course is taught in two languages, Spanish to native speakers, Group A $\left(\mathrm{n}_{1}=64, \mathrm{~N}_{1}=79\right)$, and English as a Second Language (ESL), Group B $\left(\mathrm{n}_{2}=22, \mathrm{~N}_{2}=37\right)$. The participation rate was $75.86 \%$ with a completion rate of $98.73 \%$. Data collected from the study were part of in-classroom activities that students performed in a music project. Participants consented to the use of their answers in anonymized form for research purposes. No identifiable or personal information was stored.

\subsection{Questionnaire Design}

The data were collected, analyzed, and interpreted through a questionnaire that was sent to all enrolled students. The electronic questionnaire was tested before fielding the questionnaire for testing usability and technical functionality. Additional questions, not included in this study, assessed student experience and satisfaction with the virtual experience of the musical tale project. The questionnaire had six items: three items were short open-ended questions; two were binary close-ended questions (yes/no), and one aimed at group identification (Spanish vs. ESL). All questions were laid in a single screen or page and no adaptive questioning was used. In order to guarantee the completeness of the submitted answers, all questions were marked as mandatory, providing non-response items when applicable (e.g., "rather not say"). 


\subsection{Questionnaire Administration and Data Extraction}

The questionnaire was administrated as a closed survey, since the questionnaire was restricted to students enrolled in the Music Education course. The questionnaire was advertised in class as a voluntary survey at the completion of the musical tale project and its respective assessment. No incentives were offered for replying to the questionnaire and participation carried no repercussions on the grades of students. Google Forms was used for automatically capturing the responses and items were randomized to prevent biases. To avoid duplicate responses from the same individual, the number of responses per participant was limited to one. Once the questionnaire was filled and the answers sent, respondents were not allowed to change their answers. Only completed questionnaires were analyzed. Data extraction was performed using Microsoft Excel 16.0. The verification of the extracted data was performed by both authors.

\subsection{Data Analysis}

An iterative qualitative data analysis model was followed to reduce the data collected from the students' impressions and to identify the main challenges and benefits of the online musical project [52]. The results were reported as the number of answers and the percentual weight of each item. A single category was selected in each answer, indicating the main benefit and the main challenge reported by the student. Statistical analysis on the differences in the weight of each item between groups $A$ and $B$ was performed using the students' $t$-test calculating $p$-values.

\subsection{Didactic Implementation Procedure}

In the second semester of the 2019/20 academic year, junior students of the bachelor's degree in Primary Education Teaching were asked to design and present an educational musical tale. This assignment, weighing $60 \%$ of the final grade, was an alternative to the final exam [53]. The other $40 \%$ corresponded to individual activities. In pre-pandemic times, students completed this group project as a short play in a face-to-face format. Students made use of the available spaces and materials of the Faculty of Education. However, due to COVID-19, the procedure of this project was required to change. As a result, students individually recorded their musical tales. Afterward, students edited these short videos and merged them to submit a single video [54,55].

At the beginning of the course, the professors presented and described the musical tale project and asked students to create groups comprising approximately 6-7 individuals. This resulted in 17 projects. The didactic goal of each project was the interaction of three artistic expressions (music, visual arts, and theater) framed within environmental education as a general thematic axis. The professor indicated the various stages of the project requiring, in addition to a performance, a short report that included a justification, a didactic unit (contextualization, learning goals, competences, contents, materials, methodologies, activities, and assessment), and some closing personal remarks on the overall project.

During the semester, the first wave of the COVID-19 pandemic imposed a lockdown that forced all educational activities to move online. Music Education lessons continued online, although many of the in-person musical practices needed adaptation. Students met online through video calls (Microsoft Teams) to work on their musical tales. Teamwork took place through instant messaging apps (WhatsApp) and email (Microsoft Outlook). The COVID-19 lockdown negatively affected the overall psychological state of students [56-65], which could have in turn affected student satisfaction ratings and project feedback.

\section{Results}

There were a series of issues with completing the musical tale project in an online format. The students' answers were grouped into eight items according to the similarity of the reported challenges (Table 1). The most recurring difficulty was the complexity of organizing and coordinating teamwork in a completely virtual environment. This struggle seems to be related to the second most common difficulty: dealing with the physical 
isolation imposed by COVID-19 restrictions and the lockdown. Other problems included weak internet connection and communication issues.

Table 1. Challenges expressed by the students in the online project of a musical tale.

\begin{tabular}{|c|c|c|c|c|c|c|c|}
\hline \multirow{2}{*}{ Challenges } & \multicolumn{2}{|c|}{ Group A $\left(n_{1}=64\right)$} & \multicolumn{2}{|c|}{ Group B $\left(n_{2}=22\right)$} & \multicolumn{2}{|c|}{ Total $(n=86)$} & \multirow{2}{*}{$\begin{array}{c}\text { One Tailed } \\
p \text { Value }\end{array}$} \\
\hline & $\mathbf{n}$ & $\%$ & $\mathbf{n}$ & $\%$ & $\mathbf{n}$ & $\%$ & \\
\hline Complex coordination of teamwork & 36 & 56.25 & 10 & 45.45 & 46 & 53.49 & 0.197 \\
\hline Physical isolation & 15 & 23.44 & 3 & 13.64 & 18 & 20.93 & 0.146 \\
\hline Weak internet connection & 9 & 14.06 & 1 & 4.55 & 10 & 11.63 & 0.068 \\
\hline Communication issues & 3 & 4.69 & 2 & 9.09 & 5 & 5.81 & 0.261 \\
\hline Musical content & - & - & 2 & 9.09 & 2 & 2.33 & 0.081 \\
\hline $\begin{array}{l}\text { Lack of experience in audio and } \\
\text { video editing }\end{array}$ & 1 & 1.56 & 1 & 4.55 & 2 & 2.33 & 0.270 \\
\hline $\begin{array}{c}\text { Noise pollution in domestic } \\
\text { environment }\end{array}$ & - & - & 1 & 4.55 & 1 & 1.16 & 0.164 \\
\hline Plot on environmental education & - & - & 1 & 4.55 & 1 & 1.16 & 0.164 \\
\hline Rather not say & - & - & 1 & 4.55 & 1 & 1.16 & 0.164 \\
\hline
\end{tabular}

Note. Own elaboration from data collected through questionnaire.

However, the students also identified a series of benefits from carrying out the musical tale project online (Table 2). Greater heterogeneity was found in students' responses. Students valued the interaction positively due to greater access to digital tools and an increased understanding of basic video editing. They also appreciated the interactions through social media and the possibility of using video editing and sharing apps such as TikTok. Another recurring benefit was the possibility of recording oneself as many times as needed. Students indicated that this provided psychological relaxation as they did not need to stage a final, live performance. Creativity, time management, increased comfort, and better concentration are a few of the other benefits that students indicated toward favoring online education.

Table 2. Benefits expressed by the students in the online project of a musical tale.

\begin{tabular}{|c|c|c|c|c|c|c|c|}
\hline \multirow{2}{*}{ Benefits } & \multicolumn{2}{|c|}{ Group A $\left(n_{1}=64\right)$} & \multicolumn{2}{|c|}{ Group B $\left(n_{2}=22\right)$} & \multicolumn{2}{|c|}{ Total $(n=86)$} & \multirow{2}{*}{$\begin{array}{c}\text { One Tailed } \\
p \text { Value }\end{array}$} \\
\hline & $\mathbf{n}$ & $\%$ & $\mathbf{n}$ & $\%$ & $\mathbf{n}$ & $\%$ & \\
\hline Use of ICT and video editing & 11 & 17.19 & 7 & 31.82 & 18 & 20.93 & 0.101 \\
\hline Interaction through social media & 9 & 14.06 & 5 & 22.73 & 14 & 16.28 & 0.200 \\
\hline Psychological relaxation & 10 & 15.63 & 2 & 9.09 & 12 & 13.95 & 0.202 \\
\hline Creativity, reinventing yourself & 9 & 14.06 & 1 & 4.55 & 10 & 11.63 & 0.068 \\
\hline Better use of time & 8 & 12.50 & 1 & 4.55 & 9 & 10.47 & 0.101 \\
\hline Greater comfort, no commuting & 5 & 7.81 & 2 & 13.64 & 7 & 8.14 & 0.429 \\
\hline Better concentration & 1 & 1.56 & 1 & 4.55 & 2 & 2.33 & 0.270 \\
\hline Decoration and special effects & 2 & 3.13 & - & - & 2 & 2.33 & 0.079 \\
\hline Rather not to say & 9 & 14.06 & 3 & 13.64 & 12 & 13.95 & 0.481 \\
\hline
\end{tabular}

In Table 3, the students identify the single most valuable aspect that the musical tale project had for their education training as teachers. The most reported benefit was the didactic innovation of the project and its use of active learning methodologies (project-based learning). The second most popular answer pointed to the importance of music in general education and its benefits. In total, $16.28 \%$ of the students pointed out that the main benefit of this project was that it helped them to increase their environmental awareness. The musical tales helped the students to increase their motivation in an enjoyable and positive manner. Other aspects included the relevance of the musical tale as a tool for conducting cooperative, meaningful, and interdisciplinary learning through musical activities. In the final two questions of the questionnaire, $98.84 \%$ of the students indicated that the musical tale was a useful didactic resource for promoting ecological values and environmental awareness in an interdisciplinary way. A total of $90.70 \%$ indicated that they felt prepared 
to develop this activity in primary education schools in the future. After applying the students' $t$-test, no significant differences were encountered between groups A and B, suggesting that both groups experienced similar challenges and benefits from the didactic implementation.

Table 3. Reported relevance of the musical tale as a didactic tool.

\begin{tabular}{|c|c|c|c|c|c|c|c|}
\hline \multirow{2}{*}{ Relevance } & \multicolumn{2}{|c|}{ Group A $\left(n_{1}=64\right)$} & \multicolumn{2}{|c|}{ Group B $\left(n_{2}=22\right)$} & \multicolumn{2}{|c|}{ Total $(n=86)$} & \multirow{2}{*}{$\begin{array}{c}\text { One Tailed } \\
p \text { Value }\end{array}$} \\
\hline & $\mathbf{n}$ & $\%$ & $\mathbf{n}$ & $\%$ & $\mathbf{n}$ & $\%$ & \\
\hline $\begin{array}{l}\text { Didactic innovation. Active } \\
\text { methodology }\end{array}$ & 21 & 32.81 & 5 & 22.73 & 26 & 30.23 & 0.180 \\
\hline Importance of music & 12 & 18.75 & 4 & 18.18 & 16 & 18.60 & 0.477 \\
\hline Environmental awareness & 11 & 17.19 & 3 & 13.64 & 14 & 16.28 & 0.346 \\
\hline Highly motivational, playful, and fun & 6 & 9.38 & 4 & 18.18 & 10 & 11.63 & 0.173 \\
\hline Singing, dancing, playing instruments & 6 & 9.38 & 2 & 9.09 & 8 & 9.30 & 0.485 \\
\hline Interdisciplinary context & 3 & 4.69 & 3 & 13.64 & 6 & 6.98 & 0.135 \\
\hline Use of digital technologies & 2 & 3.13 & 1 & 4.55 & 3 & 3.49 & 0.390 \\
\hline Assessment system & 1 & 1.56 & - & - & 1 & 1.16 & 0.161 \\
\hline Rather not to say & 2 & 3.13 & - & - & 2 & 2.33 & 0.079 \\
\hline
\end{tabular}

\section{Discussion}

The main limitations of this study are that (i) the didactic implementation of the musical tale was delivered in a pseudo-experimental way without a control group; (ii) this study was performed during the COVID-19 pandemic, potentially altering the student perception of online learning due to external factors; (iii) teachers did not undergo a prolonged specific training in online teaching methodologies due to the sudden and unexpected evolution of the pandemic. These limitations may partially limit the interpretation of the presented results.

There is a large amount of Spanish literature on the topic of "musical tales" (cuentos musicales or cuentos musicados, in Spanish), understood as an effective didactic resource for unifying musical expressions through the dramatization of a children's story $[29,46,49,50,54]$. Many of these studies approach the musical tale from a theoretical perspective. Arguedas Quesada [47] analyzes the activities of a musical tale highlighting its literary, musical, aural, motor, creative, and plastic components. Toboso Ontoria and Natividad [66] offer a classification of musical tales according to the nature of musical materials used (e.g., narrative songs, programmatic instrumental music, or background music to spoken word).

There are also practical proposals in the literature, with musical tales promoting environmental awareness. Montes Martín [67] shares a didactic experience called "Recycled Sounds" (Sonidos reciclados, in Spanish) which suggests the creation of recycled instruments as part of a workshop on trash and waste. The recycled instruments are used to improvise and compose the soundtrack of a musical tale in order to promote ecological awareness. García Sánchez [29] analyzed the presence of sustainability topics in the story plots of the musical fables that were created by undergraduate students of Early Childhood Education at the University of Cordoba. Although moral and environmental education had a significant presence in the story plots, many ecological topics were left undiscussed, e.g., the use of renewable energies, the inequality of natural resources, or irresponsible and unsustainable consumption.

In the literature, musical tales are understood as musical theater, where students stage and perform a children's story by making use of musical activities in-person. Therefore, this paper elaborates on the transformation of musical tales into an online format with students interacting remotely through videocalls. The questionnaire responses identified several benefits and drawbacks to working on the musical tale project in this format. The most notable challenges included the complexity involved in coordinating a group within an online environment. The internet offers many tools for connecting people, but it also presents considerable drawbacks such as increased distractions, an overflow of information, 
and the effacing of the boundary between personal life and work. These factors might have negatively affected the coordination of a team online. An added issue was the physical isolation derived from the lockdown and social distancing measures resulting from the COVID-19 pandemic.

The students also identified the many benefits of carrying out the musical tale project online. Some of the reported benefits are applicable to online education in general, e.g., there is no need to commute, greater comfort in an individual's personal space, opportunity for better concentration, and better time management. However, there are baseline requirements needed to fully gain from online education. In particular, improvement is required with regards to better concentration without distractions. It should be noted that not all students have the adequate conditions for an acoustically isolated, private space for studying at home. Some students reported that they grappled with a weak internet connection and noise pollution in the domestic environment (e.g., roommates, younger siblings, TV in the background, household chores, noisy neighbors, etc.).

The pedagogical value of the musical tale lies in its engagement with active and meaningful learning. However, when considering an online environment, deficiencies in teaching methodology can reduce learning to observation and passive repetition [68]. Students reported that working on this project helped to improve their psychological state, despite the setbacks imposed by the COVID-19 pandemic. Students positively valued the creativity, cooperative learning, and the interdisciplinary context of designing, preparing, and recording musical tales.

Music education is a fundamental area in human development with several interdisciplinary liaisons in the social, intercultural, communicative, linguistic, artistic, and environmental domains. The results of the questionnaire explore the multiple aspects that should be considered for the delivery of a successful undergraduate music education course within a virtual learning environment. Musical tales can promote ecological values through theatrical play as ecodramaturgies [42]. As Kireeva [69] points out, "the natural-oriented method in the framework of ecological approach has not lost its significance in solving vital tasks of the formation of a creatively active personality" (p. 116).

Music education should be regarded as an interdisciplinary subject that promotes sustainability and environmental awareness and helps to develop key competences that lead to integral student development. Some recommendations for teachers are that (i) the design, rehearsal, justification and staging of musical tales helps to boost students' creativity, teamwork, organization, and planning and helps their acquirement of key competences to work online in an interconnected environment; (ii) curriculum adaptations should be encouraged to address the learning needs of the students through a more integrated and holistic approach; and (iii) participation in specific training for online active methodologies should be encourage to design interdisciplinary online learning experiences.

Supplementary Materials: The following are available online at https:/ / www.mdpi.com/article/10 .3390/educsci11100582/s1, Checklist for Reporting Results of Internet E-Surveys (CHERRIES) [51].

Author Contributions: All sections of the manuscript were written by both authors. Both authors have read and agreed to the published version of the manuscript.

Funding: The APC was partially funded by the Department of Physical Education, Arts Education, and Music, Faculty of Education of Albacete, University of Castilla-La Mancha, Spain.

Institutional Review Board Statement: Ethical review and approval were waived for this study, since data were collected as part of in-classroom activities and no identifiable or personal information was gathered or stored.

Informed Consent Statement: Informed consent was obtained from all subjects involved in the study.

Data Availability Statement: The data presented in this study are available on request from the corresponding author.

Acknowledgments: The present paper is part of the research project La innovación docente interdisciplinar. Creación de actividades y recursos presenciales y virtuales para Expresión Artística en 
el Grado de Maestro en Educación Infantil y Primaria [Interdisciplinary teaching innovation. The creation of face-to-face and virtual activities and resources for Artistic Expression in the bachelor's degree in kindergarten and primary education teaching]. This project was granted by the 9th Call of Teaching Innovation Projects organized by the vice-rector's office of teaching (UCLM). The authors wish to thank Madison Gambone for carefully proofing the English language of this paper, and Iván Syroyid Syroyid for the assistance with the statistical analysis of the data. The authors express their gratitude to the students of the Faculty of Education of Albacete for participating in this study. This article was written by members of the LabinTic research group, Laboratorio de Integración de las TIC en el aula [Laboratory of Integration of ICT in the Classroom], Faculty of Education of Albacete, University of Castilla-La Mancha.

Conflicts of Interest: The authors declare no conflict of interest.

\section{References}

1. Orden ECI/3857/2007, de 27 de Diciembre, Por la Que se Establecen los Requisitos Para la Verificación de los Títulos Universitarios Oficiales Que Habiliten Para el Ejercicio de la Profesión de Maestro en Educación Primaria. Orden ECI/3857/2007, 27 December, Which Establishes the Requirements for the Verification of Official University Degrees that Qualify to the Exercise of the Profession of Teacher in Primary Education. Available online: https:/ / www.boe.es/diario_boe/txt.php?id=BOE-A-2007-22449 (accessed on 7 June 2021).

2. Orden ECI/2211/2007, de 12 de Julio, Por la Que se Establece el Currículo y se Regula la Ordenación de la Educación Primaria. Order ECI/2211/2007, 12 July, Which Establishes the Curriculum and Regulates the Management of Primary Education. Available online: https:/ / www.boe.es/eli/es/o/2007/07/12/eci2211 (accessed on 25 May 2021).

3. Cardona Henao, J.F. Procesos de Enseñanza-Aprendizaje en la Universidad: Perspectiva de los Estudiantes. Teaching-Learning Processes in the University: Students' Perspective. Rastros Rostros 2016, 18, 51-60. [CrossRef]

4. Ley Orgánica 2/2006, de 3 de Mayo, de Educación. Organic Law 2/2006, 3 May, of Education. Available online: https: //www.boe.es/eli/es/o/2015/01/21/ecd65 (accessed on 18 September 2021).

5. Levinowitz, L.M. The Importance of Music in Early Childhood. Gen. Music Today 1998, 12, 4-7. [CrossRef]

6. Lehr, M.R. Music Education: The Brain-Building Subject. Teach. Music 1998, 6, 40-56.

7. Petress, K. The Importance of Music Education. Education 2005, 126, 112-115.

8. Lamont, A. The Beat Goes On: Music Education, Identity and Lifelong Learning. Music Educ. Res. 2011, 13, 369-388. [CrossRef]

9. Bath, N.; Daubney, A.; Mackrill, D.; Spruce, G. The Declining Place of Music Education in Schools in England. Child. Soc. 2020, 34, 443-457. [CrossRef]

10. Costa-Giomi, E. The Effects of Three Years of Piano Instruction on Children's Cognitive Development. J. Res. Music Educ. 1999, 47, 198-212. [CrossRef]

11. Collins, A. Music education and the brain: What does it take to make a change? Appl. Res. Music Educ. 2013, 32, 4-10. [CrossRef]

12. Angélica Benítez, M.; Díaz Abrahan, V.; Justel, N. Beneficios del entrenamiento musical en el desarrollo infantil: Una revisión sistemática. Benefits of Music Training in Child Development: A Systematic Review. Rev. Int. Educ. Musical 2017, 5, 61-69. [CrossRef]

13. Campayo-Muñoz, E.A.; Cabedo-Mas, A. The Role of Emotional Skills in Music Education. Br. J. Music Educ. 2017, 34, 243-258. [CrossRef]

14. Marcuzzi, C.; Romero-Naranjo, F.J. BAPNE Method, Developmental Dyslexia and Inclusive Education: Cognitive, SocioEmotional and Psychomotor Stimulation in Secondary School. A Practical Resource for Education within a Cross Curriculum. Procedia-Soc. Behav. Sci. 2017, 237, 1291-1298. [CrossRef]

15. Porflitt, F.; Rosas, R. Detrás de la escena: Beneficios cognitivos de tocar un instrumento musical. Funciones ejecutivas, velocidad de procesamiento, inteligencia fluida y atención dividida. Behind the Scenes: Cognitive Benefits of Playing a Musical Instrument. Executive Functions, Processing Speed, Fluid Intelligence and Divided Attention. Estud. Psicol. 2019, 40, 476-490. [CrossRef]

16. Sabina, V.; Senad, K. Cognitive-Emotional Music Listening Paradigm in Professional Music Education. Int. J. Cogn. Res. Sci. Eng. Educ. 2021, 9, 135-145. [CrossRef]

17. Manresa Molins, M.A. Los 25 beneficios que ofrece el aprendizaje de la música. The 25 Benefits that Offer Musical Training. Melómano La Rev. Música Clásica 2021, 269, 20-24.

18. Črnčec, R.; Wilson, S.J.; Prior, M. The Cognitive and Academic Benefits of Music to Children: Facts and Fiction. Educ. Psychol. 2006, 26, 579-594. [CrossRef]

19. Sala, G.; Gobet, F. Does Far Transfer Exist? Negative Evidence from Chess, Music, and Working Memory Training. Curr. Dir. Psychol. Sci. 2017, 26, 515-520. [CrossRef]

20. Sala, G.; Gobet, F. When the Music's Over. Does Music Skill Transfer to Children's and Young Adolescents' Cognitive and Academic Skills? A Meta-Analysis. Educ. Res. Rev. 2017, 20, 55-67. [CrossRef]

21. Sala, G.; Gobet, F. Cognitive and Academic Benefits of Music Training with Children: A Multilevel Meta-Analysis. Mem. Cogn. 2020, 48, 1429-1441. [CrossRef] [PubMed] 
22. Cooper, P.K. It's All in Your Head: A Meta-Analysis on the Effects of Music Training on Cognitive Measures in Schoolchildren. Int. J. Music Educ. 2020, 38, 321-336. [CrossRef]

23. Gold, C.; Voracek, M.; Wigram, T. Effects of Music Therapy for Children and Adolescents with Psychopathology: A Meta-Analysis. J. Child. Psychol. Psychiatry 2004, 45, 1054-1063. [CrossRef]

24. Standley, J. Music Therapy Research in the NICU: An Updated Meta-Analysis. Neonatal Netw. 2012, 31, 311-316. [CrossRef]

25. Zhao, K.; Bai, Z.G.; Bo, A.; Chi, I. A Systematic Review and Meta-Analysis of Music Therapy for the Older Adults with Depression. Int. J. Geriatr. Psychiatry 2016, 31, 1188-1198. [CrossRef] [PubMed]

26. Kokotsaki, D.; Hallam, S. Higher Education Music Students' Perceptions of the Benefits of Participative Music Making. Music Educ. Res. 2007, 9, 93-109. [CrossRef]

27. Ley Orgánica 1/1990, de 3 de octubre, de Ordenación General del Sistema Educativo. Organic Law 1/1990, October 3, of General Management of the Educational System. Available online: https://www.boe.es/buscar/doc.php?id=BOE-A-1990-24172 (accessed on 3 May 2021).

28. UNESCO. Decenio de las Naciones Unidas de la Educación para el Desarrollo Sostenible, 2005-2014 UNESCO. United Nations Decade of Education for Sustainable Development, 2005-2014. Available online: https://unesdoc.unesco.org/ark:/48223/pf000 0141629_spa (accessed on 30 May 2021).

29. García Sánchez, A. Inclusión de la sostenibilidad en la formación inicial y continua del profesorado a través del cuento musicado. Inclusion of Sustainability in the Initial and Continuous Training of Teachers through Musical Fables. Dedica. Rev. Educ. E Humanid. 2019, 16, 47-63. [CrossRef]

30. Popović, A.; Bogut, I.; Crnojević, Ž.; Popović, Ž. Children's Play The Ecological Story in Function of Ecological Education of Preschool Children. Pannon. Čas. Za Humanist. Znan. 2019, 3, 169-197.

31. Tatković, N.; Diković, M.; Štifanić, M. Education for Development of Today and Tomorrow. Ecological and Social Paradigms. In Odgoj i Obrazovanje za Razvoj Danas i Sutra. Ekološke i Društvene Paradigm; Sveučilište Jurja Dobrile u Puli: Pula, Croatia, 2015.

32. Jukić, R. Ekološko pitanje kao odgojno-obrazovna potreba Environmental Questions as an Educational Need. Soc. Ekol. Čas. Za Ekološku Misao I Sociol. Istraž. Okoline 2011, 20, 267-286.

33. Pejić Papak, P. Igrom razmišljamo i djelujemo ekološki. Through Playing We Think About Acting Ecologically. In Cjeloživotno Učenje za Održivi Razvoj; Uzelac, V., Vujičić, L., Boneta, Ž., Eds.; Učiteljski fakultet Sveučilišta u Rijeci: Rijeci, Croatia, 2007; pp. 111-114.

34. Milat, J. Teze za razvoj ekološke pedagogije. Theses for the Development of Ecological Pedagogy. Školski Vjesn. Čas. Za Pedagoš. I Školska Pitanja 2006, 55, 109-118.

35. Dunlap, R.; Jones, R. Environmental Concern: Conceptual and Measurement Issues. In Handbook of Environmental Sociology; Dunlap, R.E., Michelson, W., Eds.; Greenwood Press: Westport, CT, USA, 2002; pp. 482-524.

36. Mediavilla, M.E.; Medina, S.; González, I. Diagnóstico de sensibilidad medioambiental en estudiantes universitarios. Diagnostic of Environmental Sensitivity in University Students. Educ. Educ. 2020, 23, 179-197. [CrossRef]

37. Jiménez, M.; Lafuente, R. La operacionalización del concepto de conciencia ambiental en las encuestas. The Operationalization of the Environmental Conscience in the Questionnaires. In Persona, Sociedad y Medio Ambiente. Perspectivas de la Investigación Social de la Sostenibilidad; de Castro, R., Ed.; Dirección General de Educación Ambiental y Sostenibilidad: Sevilla, Spain, 2006; pp. 121-150.

38. Corraliza, J.A.; Berenguer, J.; Moreno, M.; Martín, R. La investigación de la conciencia medioambiental. Un enfoque psicosocial. The Research of the Environmental Conscience. A Psychosocial Approach. In Persona, Sociedad y Medio Ambiente. Perspectivas de la Investigación Social de la Sostenibilidad; de Andalucía, J., Ed.; Consejería de Medio Ambiente: Sevilla, Spain, 2006; pp. 106-120.

39. Febles Elejalde, M.; Pérez Iglesias, D.; Ramos Martínez, D. Psicología y conciencia ambientales. Un enfoque teórico para el desarrollo de la conciencia ambiental, hacia el desarrollo sostenible. Psychology and Environmental Conscience. A Theoretical Approach to the Development of Environmental Conscience, Towards Sustainable Development. Energía Tú 2004, 57, 231-244.

40. Van Liere, K.D.; Dunlap, R.E. The Social Bases of Environmental Concern: A Review of Hypotheses, Explanations and Empirical Evidence. Public Opin. Q. 1980, 44, 181-197. [CrossRef]

41. Curtis, D.J.; Reid, N.; Reeve, I. Towards Ecological Sustainability: Observations on the Role of the Arts. Surv. Perspect. Integr. Environ. Soc. 2014, 7, 1-15.

42. Woynarski, L. Ecodramaturgies: Theatre, Performance and Climate Change; Springer Nature: Basingstoke, UK, 2020.

43. Pérez Molina, A.I.; Pérez Molina, D.; Sánchez Serra, R. El cuento como recurso educativo. The Tale as an Educative Resource. Empresa Investig. Pensam. Crít. 2013, 2, 4.

44. Rogalska-Marasińska, A. Effects of Using Musical Fairy Tales in the Classroom: Action Research in Poland. J. Lang. Cult. Educ. 2018, 6, 48-70. [CrossRef]

45. Rabal Alonso, J.M.; Ganga Cano, A.; Bermejo Zárate, M.; González Romero, M. Didáctica a través de los cuentos en educación infantil: ¿por qué es importante el uso del cuento? Didactics through Tales in Early Childhood Education: Why is the Use of Tales Important? Braz. J. Dev. 2020, 6, 102285-102307. [CrossRef]

46. De Moya Martínez, M.V. El cuento musical y la educación en valores en edad infantil. The Musical Tale and Value-Based Education in Childhood. In Ética, Estética y Estrategias Didácticas en Educación Infantil; Prada García, C., Ed.; Grupo de Investigación "Educación Infantil y Formación de Educadores", Universidades de Andalucía: Málaga, Spain, 2015; pp. $273-282$.

47. Arguedas Quesada, C. Cuentos musicales para los más pequeños. Musical Tales for the Little Ones. Rev. Electrón. Actual. Investig. En Educ. 2006, 6, 1-22. 
48. Carreño, M. Literatura y juego teatral Literature and the Theatrical Play. Rastros Rostros 2001, 4, 51-54.

49. García Sánchez, A. El cuento musicado. La interdisciplinariedad al servicio de la interculturalidad. The Musical Fable. Interdisciplinarity at the Service of Interculturality. Dedica. Rev. Educ. E Humanid. 2016, 10, $29-41$.

50. De Vicente-Yagüe Jara, M.I.; Guerrero Ruiz, P. El cuento musical. Análisis de sus componentes textuales, musicales e ilustrados para el desarrollo de las competencias básicas en educación primaria. The Musical Tale. Analysis of its Textual, Musical, and Visual Components for the Development of Basic Competences in Primary Education. Profesorado. Rev. Currículum Form. Profr. 2015, 19, 398-418.

51. Eysenbach, G. Improving the quality of Web surveys: The Checklist for Reporting Results of Internet E-Surveys (CHERRIES). J. Med. Int. Res. 2004, 6, e132. [CrossRef]

52. Miles, M.B.; Huberman, A.M. Qualitative Data Analysis: An Expanded Sourcebook; Sage Publications: London, UK, $1994 ;$ pp. 10-12.

53. Universidad de Castilla-La Mancha. Guía Docente de la Asignatura Educación Musical, Curso Académico 2019-2020; Didactic guide of the Music Education course. Academic year 2019-2020; Facultad de Educación de Albacete: Albacete, España, 2020.

54. Syroyid Syroyid, B.; De Moya Martínez, M.V. Reinventando recursos didácticos: El vídeo-cuento musical en Educación Primaria. Reinventing Didactic Resources: The Musical Video-Tale in Primary Education. In Actas del Congreso Internacional Virtual USATIC 2020, Ubicuo y Social: Aprendizaje con TIC; Alejandre Marco, J.L., Allueva Pinilla, A.I., Eds.; Servicio de Publicaciones Universidad de Zaragoza: Zaragoza, Spain, 2020; p. 97.

55. Hernández Bravo, J.A. El vídeo-cuento: Narración, imagen y sonido en Educación Infantil. The Video Tale: Narration, Image and Sound in Preschool Education. In Las TIC En El Aula Desde Un Enfoque Multidisciplinar: Aplicaciones Prácticas; Cózar Gutiérrez, R., de Moya Martínez, M.V., Eds.; Octaedro: Barcelona, Spain, 2013; pp. 125-138.

56. Rodríguez-Rey, R.; Garrido-Hernansaiz, H.; Collado, S. Psychological Impact and Associated Factors During the Initial Stage of the Coronavirus (COVID-19) Pandemic Among the General Population in Spain. Front. Psychol. 2020, 11, 1540. [CrossRef]

57. Rodríguez-Larrad, A.; Mañas, A.; Labayen, I.; González-Gross, M.; Espin, A.; Aznar, A.; Serrano-Sánchez, J.A.; Vera-García, F.J.; González-Lamuño, D.; Ara, I.; et al. Impact Of COVID-19 Confinement On Physical Activity And Sedentary Behaviour In Spanish University Students: Role Of Gender. Int. J. Environ. Res. Public Health 2021, 18, 369. [CrossRef]

58. Ezpeleta, L.; Navarro, J.B.; De La Osa, N.; Trepat, E.; Penelo, E. Life Conditions During COVID-19 Lockdown and Mental Health in Spanish Adolescents. Int. J. Environ. Res. Public Health 2020, 17, 7327. [CrossRef]

59. Garvey, A.M.; García, I.J.; Otal Franco, S.H.; Fernández, C.M. The Psychological Impact of Strict and Prolonged Confinement on Business Students during the COVID-19 Pandemic at a Spanish University. Int. J. Environ. Res. Public Health 2021, 18, 1710. [CrossRef] [PubMed]

60. Gómez-Salgado, J.; Andrés-Villas, M.; Domínguez-Salas, S.; Díaz-Milanés, D.; Ruiz-Frutos, C. Related Health Factors of Psychological Distress During the COVID-19 Pandemic in Spain. Int. J. Environ. Res. Public Health 2020, 17, 3947. [CrossRef] [PubMed]

61. González-Bernal, J.J.; Santamaría-Peláez, M.; González-Santos, J.; Rodríguez-Fernández, P.; León del Barco, B.; Soto-Cámara, R. Relationship of Forced Social Distancing and Home Confinement Derived from the COVID-19 Pandemic with the Occupational Balance of the Spanish Population. J. Clin. Med. 2020, 9, 3606. [CrossRef] [PubMed]

62. Romero, E.; López-Romero, L.; Domínguez-Álvarez, B.; Villar, P.; Gómez-Fraguela, J.A. Testing the Effects of COVID-19 Confinement in Spanish Children: The Role of Parents' Distress, Emotional Problems and Specific Parenting. Int. J. Environ. Res. Public Health 2020, 17, 6975. [CrossRef] [PubMed]

63. Iglesias-Sánchez, P.P.; Vaccaro Witt, G.F.; Cabrera, F.E.; Jambrino-Maldonado, C. The Contagion of Sentiments During The COVID-19 Pandemic Crisis: The Case of Isolation in Spain. Int. J. Environ. Res. Public Health 2020, 17, 5918. [CrossRef]

64. Gutiérrez-Hernández, M.E.; Fanjul, L.F.; Díaz-Megolla, A.; Reyes-Hurtado, P.; Herrera-Rodríguez, J.F.; Enjuto-Castellanos, M.D.P.; Peñate, W. COVID-19 Lockdown and Mental Health in a Sample Population in Spain: The Role of Self-Compassion. Int. J. Environ. Res. Public Health 2021, 18, 2103. [CrossRef]

65. Domínguez-Salas, S.; Gómez-Salgado, J.; Andrés-Villas, M.; Díaz-Milanés, D.; Romero-Martín, M.; Ruiz-Frutos, C. PsychoEmotional Approach to the Psychological Distress Related to the COVID-19 Pandemic in Spain: A Cross-Sectional Observational Study. Healthcare 2020, 8, 190. [CrossRef]

66. Toboso Ontoria, S.; Viñuales, N. El cuento musical: Otra forma de contar el cuento. J. Parents Teach. 2007, 307, 12-16.

67. Montes Martín, M. Sonidos reciclados. Revista Dig. Práct. Docente 2007, 6, 1-10.

68. Huergo Tobar, P.L. Estrategias de enseñanza-aprendizaje a través de videoconferencias. Strategies for Teaching-Learning Through Videoconferences. Rastros Rostros 2015, 17, 65-76. [CrossRef]

69. Kireeva, N.Y. Theatre Music and the Development of Personality: Ecological Approach. Вестник Кемеровского Государственного Университета Культуры и Искусств 2020, 50, 111-118. 